\title{
Tribo-Mechanical and Electrochemical Properties of Carbonitrided 316 Austenitic Stainless Steel by rf Plasma for Biomedical Applications
}

\author{
F. M. El-Hossary, M. Raaif, A. M. Abd El-Rahman, M. Abo EL-Kassem \\ Physics Department, Faculty of Science, Sohag University, Sohag, Egypt \\ Email: mraaif@daad-alumni.de
}

How to cite this paper: El-Hossary, F.M., Raaif, M., Abd El-Rahman, A.M. and Abo EL-Kassem, M. (2018) Tribo-Mechanical and Electrochemical Properties of Carbonitrided 316 Austenitic Stainless Steel by rf Plasma for Biomedical Applications. Advances in Materials Physics and Chemistry, 8, 358-377.

https://doi.org/10.4236/ampc.2018.89024

Received: August 1, 2018

Accepted: September 11, 2018

Published: September 14, 2018

Copyright $\odot 2018$ by authors and Scientific Research Publishing Inc. This work is licensed under the Creative Commons Attribution International License (CC BY 4.0).

http://creativecommons.org/licenses/by/4.0/

\section{(c) (i) Open Access}

\begin{abstract}
AISI 316 austenitic stainless steel was carbonitrided using rf plasma with purpose of using low-cost orthopedic implant materials in biomedical applications besides the manufacturing requests. The plasma treatment process was accomplished at low working gas pressure of 0.075 mbar in nitrogen-acetylene gaseous mixture. The plasma-processing time was fixed at $10 \mathrm{~min}$ while the plasma-processing power was varied from 450 to 650 watt. The effect of plasma treatment power on the structure, tribological, mechanical, electrochemical and biocompatibility of AISI 316 has been investigated. The structural results demonstrated the formation of nitrogen and carbon solid solutions, chromium nitride, iron carbide and iron nitride phases in the treated samples. The microhardness of the treated layer increases with increasing the processing power to reach a maximum value of approximately $1300 \mathrm{HV} 0.1$ at $600 \mathrm{~W}$ which represents more than 6-folds increase in microhardness in comparison with the untreated matrix. The wear and corrosion resistance of the treated AISI 316 were enhanced compared to the untreated one. The friction coefficient was reduced from nearly 0.5 for the untreated substrate to nearly 0.3 for the carbonitrided sample. The surface energy and wettability of the carbonitrided samples were augmented as the plasma-processing power increased. Furthermore, the numbers of grown mesenchymal stem cells are higher for carbonitrided samples compared to the untreated one. The formation of nitrogen and carbon solid solution, chromium nitride, iron nitride and iron carbide hard phases after carbonitriding process is responsible for achieving good mechanical, tribological, biocompatibility and electrochemical properties for AISI 316 alloys.
\end{abstract}




\section{Keywords}

Plasma-Material Interactions 52.40.Hf, Surface Hardening 81.65.Lp,

Mechanical Properties 62.20.Qp, Surface Energy 68.35.Md,

Biocompatibility 87.85.Jj

\section{Introduction}

Austenitic stainless steels (ASS) are broadly engaged in many manufacturing applications owing to their non-magnetic properties and consistent corrosion performance. Food processing, pulp and paper chemical, petrochemical as well as medical and pharmaceutical machinery are among of their applications. However, their low surface hardness and meager wear characteristics lead to inadequate tribo-mechanical properties which weaken their use in many probable applications [1]. Several previous studies have been potentially reported on the effect of plasma surface modification on improving the physical and chemical properties of austenitic stainless steel alloys such as active screen plasma [2], plasma electrolytic nitrocarburising [3], pulsed dc plasma [4], radio-frequency plasma [5] [6] and atmospheric pressure plasma [7]. Amongst these, rf plasma nitriding, carburizing and carbonitriding of stainless steel alloys are still used as operative techniques owing to achieving modified layers underneath with high diffusion rate at comparatively low temperature [8] [9]. Further, nitrogen or carbon insertion into austenitic lattice at low temperature tends to form solid solution phases with exceptional properties [10] [11] [12]. The solid solution phases have been found to improve the tribo-mechanical performance while keeping their excellent resistance to acidic and alkaline corrosive media [6] [9]. Furthermore, plasma treatment at low temperature hinders the random formation of chromium nitrides or carbides in the modified surface layer, which cause the corrosion degradation [13].

The current study emphases on improving the tribo-mechanical, electrochemical and biocompatibility properties of AISI 316 by rf plasma. The contact angle and surface energy of the carbonitrided layers as a function of plasma-processing power were studied. Moreover, the adhesion of mesenchymal stem cells is correlated to the physiochemical and surface topography features in order to preliminary gage the biocompatibility performance. Some of these properties are the main factors controlling the in-service performance of the AISI 316 stainless steel for many industrial and bio-medical applications.

\section{Experimental Work}

\subsection{Sample Preparation}

In the present study, AISI 316 austenitic stainless steel was used as a substrate. It was cut into small pieces of $10 \mathrm{~mm} \times 10 \mathrm{~mm} \times 1 \mathrm{~mm}$ from $1 \mathrm{~mm}$ thick rolled sheet. The chemical composition of the matrix in wt\% is: $0.024 \mathrm{C}, 1.35 \mathrm{Mn}, 16.87$ 
$\mathrm{Cr}, 10.05 \mathrm{Ni}, 2.06 \mathrm{Mo}, 0.031 \mathrm{P}, 0.029 \mathrm{~S}$ and Fe balance. The specimens were ultrasonically cleaned in acetone bath for $10 \mathrm{~min}$ before they were inserted into the plasma reactor tube. The AISI 316 austenitic substrates were carbonitrided using radio frequency $\mathrm{rf}$ plasma inductively coupled working in continuous mode of operation. Details of the carbonitriding system can be found somewhere else [14]. In brief, the rf plasma system is comprised of a quartz reactor tube with length of $500 \mathrm{~mm}$ and a diameter of $41.5 \mathrm{~mm}$ and it was evacuated to a base pressure of $10 \times 10^{-3} \mathrm{mbar}$ by a two-stage rotary pump. A gas mixture of $85 \%$ nitrogen and $15 \%$ acetylene was introduced and the gas flow rates were attuned to establish a total gas pressure of $7.5 \times 10^{-2} \mathrm{mbar}$ as measured by a capacitance manometer. The induction copper coil was energized by a $13.65 \mathrm{MHz}$ rf power generator (model HFS $2500 \mathrm{D}$ ) via a tunable matching network. The specimens were supported on a water-cooled copper sample holder and the water cooling rate of the substrate was adjusted to be $1300 \mathrm{~cm}^{3} / \mathrm{min}$. The specimen temperature was measured during the rf plasma process by a Chromel-Alumel thermocouple, which was placed close to the surface of the sample. The specimens were treated at a fixed plasma-processing time of $10 \mathrm{~min}$ and for different plasma processing powers varied from 450 to 650 watts. It is important to state that, this treatment process was performed without using any external source of heating. After carbonitriding process, the specimens were allowed to cool slowly to the room temperature in the evacuated reactor plasma tube.

\subsection{Sample Testing and Characterization}

Different techniques have been used to test and characterize the untreated and carbonitrided AISI 316 samples. X-ray diffraction (XRD) using Philips-PW1710 diffractometer with Co $\mathrm{K}_{\alpha}$ radiation of $\lambda=1.78896 \AA$ was used to characterize the phase constitution of the treated and untreated surface. The XRD scan was run between $40^{\circ}$ to $100^{\circ}$ with step interval of $0.02^{\circ}$ and scan rate of $2^{\circ} / \mathrm{min}$. The treated samples were exposed to standard metallographic procedure including sectioning, mounting, grinding, polishing and etching. Glow discharge optical spectroscopy (GDOS) is used as a technique for studying the elemental concentration depth profiles of the carbonitrided samples. The surface and cross-section morphologies of the untreated and carbonitrided AISI 316 specimens were investigated using Olympus BX51 optical microscope.

Vickers microhardness measurements of the untreated and carbonitrided AISI 316 samples were carried out using a Leitz Durimet microhardness tester with a contact load of 100 gmf. The microhardness measurements were performed according to ASTM E384-11 standard test method at temperature of $25^{\circ} \mathrm{C} \pm 3^{\circ} \mathrm{C}$ [15]. The microhardness tester has been accredited according to ISO/IEC 17025:2005 requirements. The wear measurements were performed according to ASTM G 133-10 standard test method at room temperature in air atmosphere with humidity of $35 \%-40 \%$ using an oscillating ball-on-disk type tribometer wear tester without lubrication. The $3 \mathrm{~mm}$ aluminum oxide ball moves at a mean sliding speed of $30 \mathrm{~mm} / \mathrm{s}$ with a normal load of $2 \mathrm{~N}$ has been 
used. The wear track profile has been investigated using surface profilemeter. During the measurements, the track depth and the track width can be determined from the cross-sectional profile. For more accuracy, three measurements were taken in the same wear track. Taken the average of the three profile area and multiplied by the track length the wear volume loss can be calculated. During the wear measurements, the recording of the friction coefficient was continuously measured by using a force sensor. The oscillating ball-on-disk type tribometer wear tester is accredited according to ISO/IEC 17025:2005 requirements. The surface roughness of the investigated samples was performed using a Form Talysurf 50 surface profilemeter which has been accredited according to ISO/IEC 17025:2005 requirements. The Electrochemical experiments were performed in Ringer's solution by Gill AC instrument using potentiodynamic technique at temperature of $25^{\circ} \mathrm{C} \pm 3^{\circ} \mathrm{C}$ and humidity of $38 \% \pm 5 \%$. The effective area of samples exposed to corrosive solution was fixed at $0.36 \mathrm{~cm}^{2}$. The corrosion test was performed using three-electrodes; silver-silver chloride saturated electrode as a reference electrode, platinum as a counter electrode and the investigated sample as a working electrode. Before immersing into the solution, the treated and untreated specimens were ultrasonically cleaned in acetone. The potential-current corrosion curve is recorded and plotted with potential scan rate of $1 \mathrm{mV} / \mathrm{s}$ using ACM program version 5. The water contact angle measurement, at room temperature, was performed using Phoenix 300 (Contact Angle Analyzer manufactured by SEO Co. Ltd). The Phoenix 300 utilized with a precision camera and an advanced PC technology to capture the static droplet image and calculate the contact angle measurement by Sessile Drop Method. The biocompatibility performance for the untreated and carbonitrided AISI 316 specimens was preliminary evaluated via examining the adhesion of mesenchymal stem cells (was taken from Wharton's jelly of the human umbilical cord). Before initiating the biocompatibility test, the specimens were cleaned by alcohol $70 \%$ and sterilized in autoclave (KGemmyFA-260MA) for 40 minutes. The investigated specimens were inserted into 24 well plat at appropriate concentration of 100000 cells/well. The mesenchymal stem cells were cultured in a culture flasks using RPMI and DEEM Medium supplemented with $10 \%$ fetal bovine serum and incubated at $37^{\circ} \mathrm{C}$ and $5 \% \mathrm{CO}_{2}$ under humidified conditions. After $48 \mathrm{hrs}$, the specimens were washed and the cells fixed by $4 \%$ paraformaldehyde. The specimens were stained with Acridine Orange fluorescent [16] to demonstrate the cells adhesion on the surface. The surface of the specimen was investigated by fluorescent microscope [17].

\section{Results and Discussion}

\subsection{Temperature of the Treatment}

Figure 1 shows the correlation between the temperature of the treatment and the plasma power input. It has been detected that the temperature of the treatment increases as the plasma-processing power increases. As previously reported, the surface treatment by rf plasma permits fast temperature steadiness 
and good plasma stability. A maximum of two minutes from the beginning of the process is completely enough to attain stabilized plasma and working temperature [18]. This is attributed to the good controlling in the plasma system and small size of the reactor tube ( $4 \mathrm{~cm}$ diameter) in which high plasma density is created. It has been recognized for the same rf plasma system that, the plasma power controls the electron temperature and plasma ion density which have significant influence on the temperature of the treatment and the nature of chemical reactions between plasma species and the surface of the immersed substrate [18]. Therefore, it is more convenient to consider the treatment temperature as an effective treatment parameter in discussing the current presented results.

\subsection{Elemental Depth Profile and Carbonitriding Rate}

Figure 2 displays the typical optical cross-section of the carbonitrided AISI 316

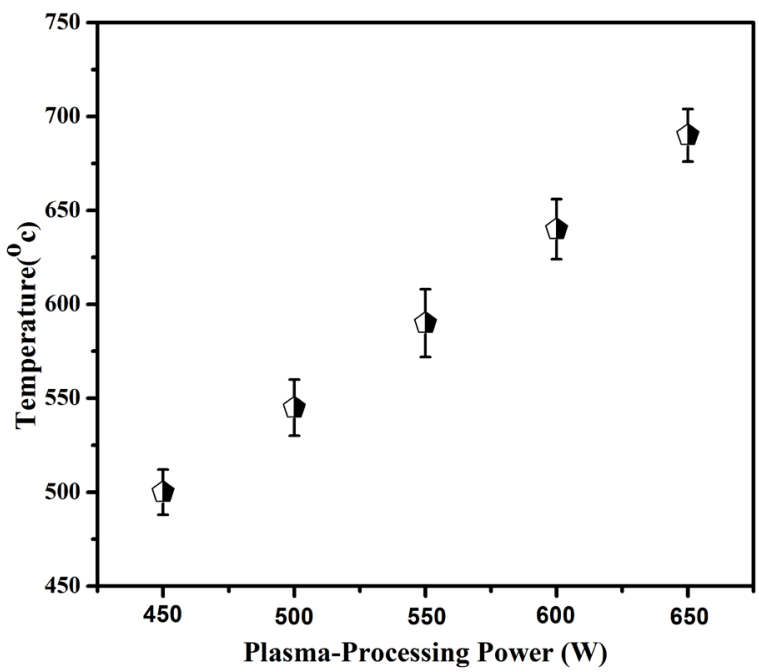

Figure 1. Temperature of the treatment variation as a function of plasma power input.

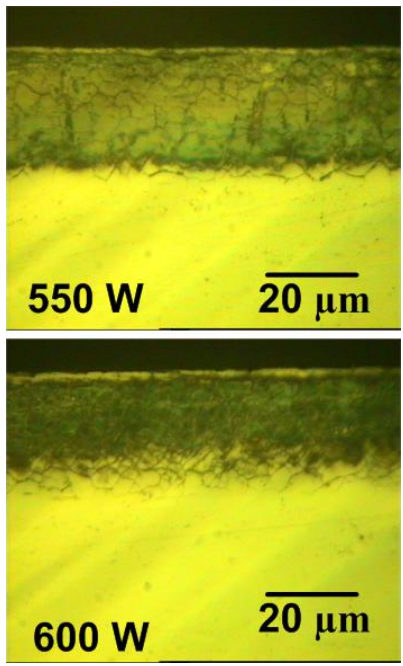

Figure 2. Cross-sections morphology of plasma carbonitrided AISI 316 at plasma-processing powers of 550 and $650 \mathrm{~W}$. 
at plasma-processing powers of 550 and $650 \mathrm{~W}$. This figure illustrate that the compound layer of the tow samples have homogeneous band of nearly uniform thickness and sharp edge with the bulk matrix. Moreover, one can observe from the figure that the compound layer comprises of two sub-layers, the first one on the top of the compound layer which can be endorsed to the formation of $\mathrm{CN}$ amorphous layer and is previously reported by Abd El-Rahman [19]. The second one is devoted for the formation of crystalline carbonitrided and nitrided austenitic stainless phases.

Figure 3(a) and Figure 3(b) show the nitrogen and carbon depth profiles for the samples that were carbonitrided at plasma-processing powers of 550 and $600 \mathrm{~W}$. one can observe from Figure 3(a) that the nitrogen concentration decreases significantly in the first five micrometers on the top layer. Afterward, the nitrogen establishes saturation concentration region up to nearly 20 micrometers, then it sharply decreases. For carbon concentration depth profile as shown in Figure 3(b) one can clearly detect that, the carbon is very high on the top layer and it decreases sharply as the depth of the compound layer increases. The carbon increases again at the end of the carbonitrided layer then it decreases towards the bulk of the specimen.

At the inauguration of the carbonitriding process, carbon diffusion in austenitic steel is faster than nitrogen diffusion. The nitrogen species start to form a nitrided layer, which pushes the carbon species toward the untreated part. The nitrided layer is continuously growing through the diffusion of highly active nitrogen species until forming nitrogen supper-saturation region which block the inward diffusion of carbon and nitrogen species. Afterward, the near surface region of the carbonitrided layer becomes supersaturated with carbon and nitrogen. The supersaturated surface defeats the diffusion process of nitrogen/carbon species into the surface. This promotes the deposition of an amorphous carbide or carbonitride/crystalline structure and leads to high concentration of nitrogen and carbon in the top layer compared to that investigated underneath [19] [20].

Figure 4 elucidates the variation of the treated layer thickness and carbonitriding rate as a function of plasma-processing power. The carbonitrided thickness is calculated as the average value of the compound layer thickness taken from five different locations on the cross-section view. The carbonitriding rate is calculated using the formula of $\mathrm{d}^{2} / \mathrm{t}$, where $\mathrm{d}$ is the average thickness of the treated layer in $\mu \mathrm{m}$ and $\mathrm{t}$ is the plasma-processing time in sec. For the sample treated at a relatively low plasma-processing power of $450 \mathrm{~W}$, the thickness and the rate of the carbonitrided layer were relatively small and have values of $6 \mu \mathrm{m}$ and $0.06 \mu \mathrm{m}^{2} / \mathrm{sec}$, respectively. This is mostly due to the residual surface oxide layer which prevents the diffusing of carbon and nitrogen into the treated surface [21]. However, with increasing the processing power up to $500 \mathrm{~W}$, the thickness and the rate of the carbonitrided layer increase dramatically to reach values of $25 \mu \mathrm{m}$ and $1.04 \mu \mathrm{m}^{2} / \mathrm{sec}$, respectively. A continuous increase in the processing power leads to achieve higher values of thickness and carbonitriding rate. It is previously reported that, at certain conditions of treatment tempera- 
ture and time, surface porous and microcracks are grown in number and size during plasma surface treatment of stainless steel [14] [19]. These surface micro-defects work as effective channels in addition to natural diffusion path through the grain boundaries for diffusing nitrogen and carbon into deeper bulk substrate [22]. The variation in reactive plasma species concentration close to the sample surface with varying plasma processing powers is considered as a further contributing factor for enhancing the diffusion process [22] [23]. These parameters are frequently responsible for forming thicker carbonitrided layers and higher growth rates. After convinced period and power of plasma process, the inward carbonitrided species might block the formerly formed porous and microcracks in the treated layer. Consequently, the diffusion of the carbonitrided species will be increased with low rate or steady state.
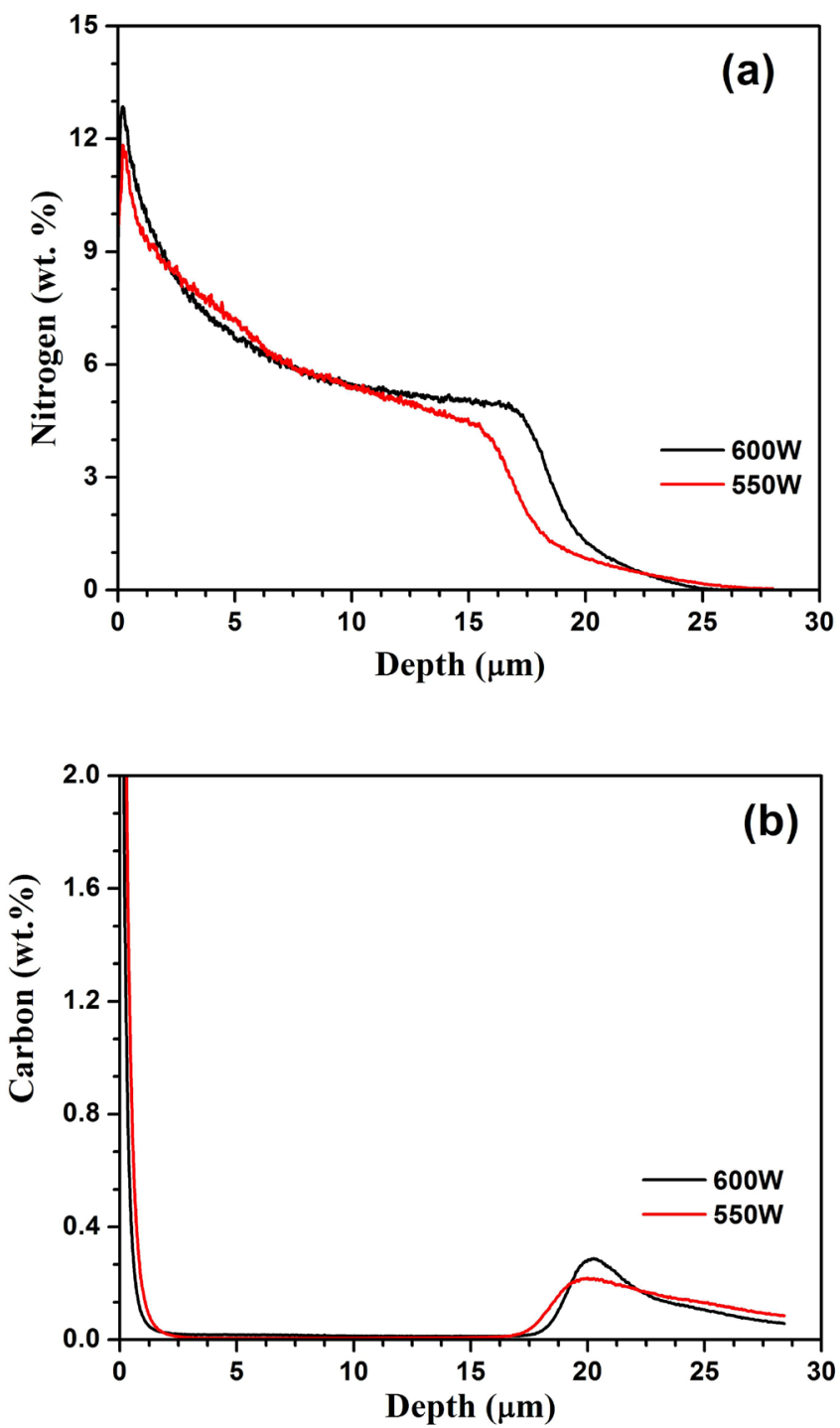

Figure 3. Elemental depth profile (a) Nitrogen depth profile; (b) Carbon depth profile of plasma carbonitrided AISI 316 at plasma-processing powers of 550 and $600 \mathrm{~W}$. 


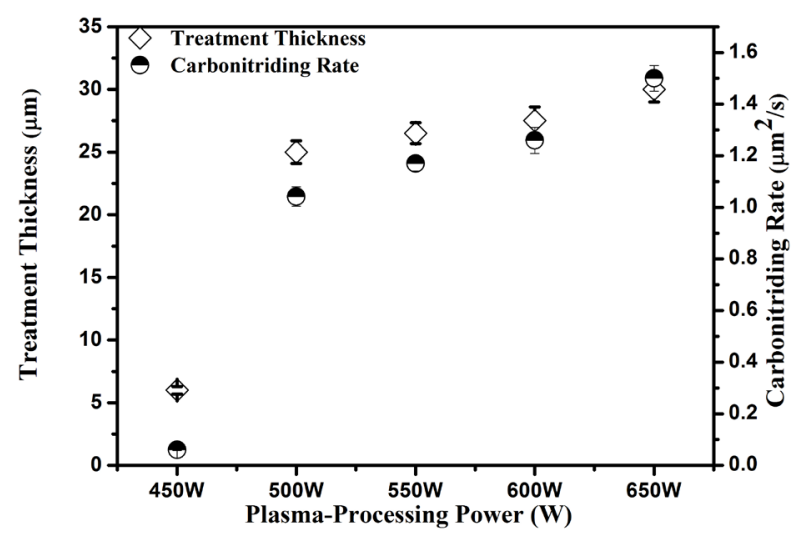

Figure 4. Case depths and Carbonitriding rate as a function of plasma-processing power.

\subsection{Microstructure Analysis}

Figure 5 shows the phase configuration of the untreated and carbonitrided AISI 316 samples as characterized by XRD analysis. The XRD spectra of the untreated substrate confirms the presence of austenitic phases, while the spectra of the carbonitrided substrate designate the existence of chemical compounds of $\mathrm{FeC}$, $\mathrm{Fe}_{3} \mathrm{C}, \mathrm{Fe}_{4} \mathrm{~N}$ and $\mathrm{CrN}$ phases and solid solution of $\gamma_{\mathrm{N}}$ and $\gamma_{\mathrm{C}}$ phases (JCPDS card number 33:0397, JCPDS card number 11:0065, JCPDS card number 03:0964). It has been observed that, the phase constitution including the peak intensity and peak area is depending on the treatment temperature. Further, XRD spectra for the solid solution phases display peak shifts of the Bragg reflections and peak broadening when compared with the fcc structure of $\gamma$-austenite. The peak shift and broadening is controlled by the interstitial diffusion of carbon and nitrogen atoms into austenitic lattice and consequently lead to stress formation in the nitrided layer [24] [25]. One can witness from the figure that, the chemical compounds of iron carbide $\left(\mathrm{FeC}, \mathrm{Fe}_{4} \mathrm{C}\right)$ and $\gamma_{\mathrm{C}}$ are observed in the carbonitrided samples treated at low processing temperature of $500^{\circ} \mathrm{C}$, while no evidence for the formation of $\mathrm{CrN}$. On the other hand, $\mathrm{Fe}_{4} \mathrm{~N}, \mathrm{CrN}$ and $\gamma_{\mathrm{N}}$ are detected for the samples treated at processing temperatures higher than $545^{\circ} \mathrm{C}$. The formation of $\mathrm{CrN}$ during the growth of the nitride structures is ascribed to two reasons: Firstly, the diffusivity of substitution atoms increases as the treatment temperature increases. Secondly, the nitrogen solid solution $\gamma_{\mathrm{N}}$ is a meta-stable phase and can decompose to create $\mathrm{CrN}$ when the temperature is higher than $500^{\circ} \mathrm{C}$ [26] [27]. It is observed that, nitrogen expanded austenite has higher peak shift of about $5 \%$ compared with that of carbon expanded austenite which was about $1 \%$ [26]. This leads to higher stress formation for nitrogen expanded austenite compared to that of carbon. The present results show a lattice expansion values along (111) and (200) with about $200 \%$ larger than for the (220) direction. The low stress in the (220) direction reduces the lattice expansion in the (220) direction with respect to other planes. This lattice distortion is mostly ascribed to the sliding effects in the fcc structure which causes an inhomogeneous distribution of internal stress along the crystallite planes [11]. 


\subsection{Mechanical and Tribological Properties}

\subsubsection{Surface Microhardness}

Figure 6 illuminates the microhardness values for the untreated and the plasma carbonitrided samples at different plasma powers input. As shown in the figure, the hardness increases as the plasma power increases to reach a maximum value of $1300 \mathrm{HV} 0.1$ at plasma power of $600 \mathrm{~W}$. That represents more than 6-fold growth in the microhardness in comparison with the untreated matrix. Afterward, the microhardness decreases to reach a value of $808 \mathrm{HVO} 0.1$ at a plasma power of $650 \mathrm{~W}$. The formation of $\mathrm{FeC}, \mathrm{Fe}_{3} \mathrm{C}, \mathrm{Fe}_{4} \mathrm{~N}, \gamma_{\mathrm{N}}$ and $\gamma_{\mathrm{C}}$ in the treated layer and the precipitation of $\mathrm{CrN}$ on the grain boundaries are the main reasons for the increment in the hardness. The higher hardness values observed for the samples treated at plasma powers higher than $450 \mathrm{~W}$ are ascribed to the high amount of $\gamma_{\mathrm{N}}$ and $\gamma_{\mathrm{C}}$ phases and the precipitation of $\mathrm{CrN}$ on the grain boundaries of AISI 316 matrix [28]. The decrease in the microhardness at higher plasma power of $650 \mathrm{~W}$ is attributed to the low intensity of $\gamma_{\mathrm{N}}$ and $\gamma_{\mathrm{C}}$ phases at higher temperature [26] [27].

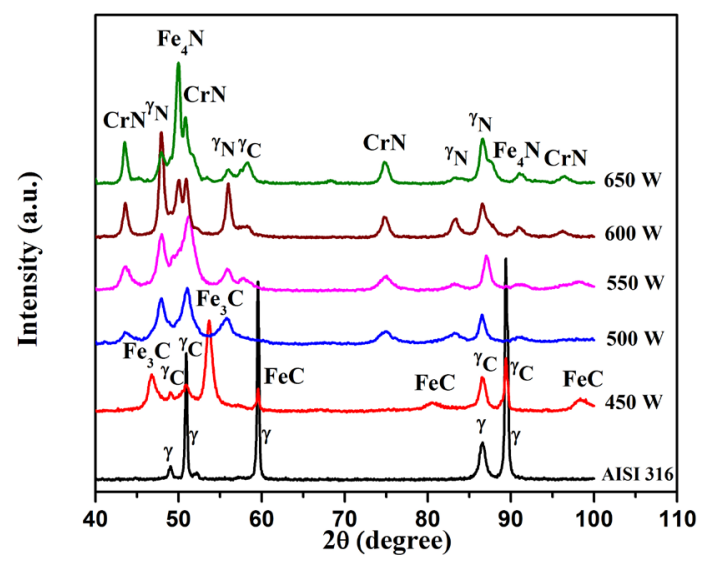

Figure 5. X-ray diffractgrams of the untreated and carbonitrided AISI 316 at different plasma-processing powers.

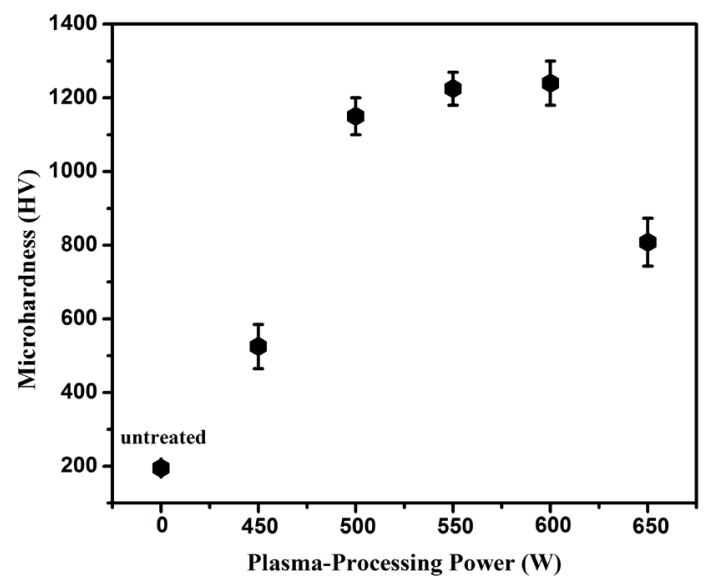

Figure 6. The microhardness values of the untreated and carbonitrided AISI 316 at different plasma-processing powers. 


\subsubsection{Wear Performance}

Figure 7 and Figure 8 display the friction coefficient and wear volume loss of the untreated and carbonitrided AISI 316 at different plasma powers, respectively. Generally, it can be observed from the two figures that the carbnitrided layers exhibit low friction coefficient as well as much lower wear volume loss compared the untreated matrix. This reflects poor wear resistance for the untreated substrate in comparison with the carbonitrided samples. This is well approved via observing wide wear tracks on the untreated matrix compared to the carbonitrided ones as shown in Figure 9. This augmentation in wear resistance is attributed to the change in wear mechanism from adhesive in the presence of native oxide layer for metallic substrate to mild abrasive for the carbonitrided ones. The formation of hard phases of $\mathrm{FeC}, \mathrm{Fe}_{3} \mathrm{C}, \mathrm{Fe}_{4} \mathrm{~N}$, and solid solutions of $\gamma_{\mathrm{N}}$ and $\gamma_{\mathrm{C}}$ in the carbonitrided layer is responsible for the working of mild abrasive wear. Moreover, Terent'ev et al. [29] attributed the improvement in the mechanical and tribological properties to the surface strengthening resulted from the formation of carbon/nitrogen solid solution and the precipitation of $\mathrm{CrN}$ on the grain boundaries of the treated austenitic stainless steel. The reduction in the friction coefficient is attributed to the chemical composition of the modified surface which is mainly composed of solid solution phases that contains a large volume fraction of nitrogen and carbon species and other chemical compound phases compared with the metallic nature of austenitic substrate [28] [30].

\subsection{Surface Roughness and Wettability}

It is well known that, some of physical surface properties such as surface hardness [31], friction coefficient [32] and surface wettability [33] can be affected by surface topography and the chemical stoichiometry of the grown structure in the treated surface. The Ra parameter describes the surface roughness and is defined as the mean height of peaks and valleys grown on the surface. Figure 10 shows the $\mathrm{Ra}$ for the untreated and carbonitrided AISI 316 as a function of plasma

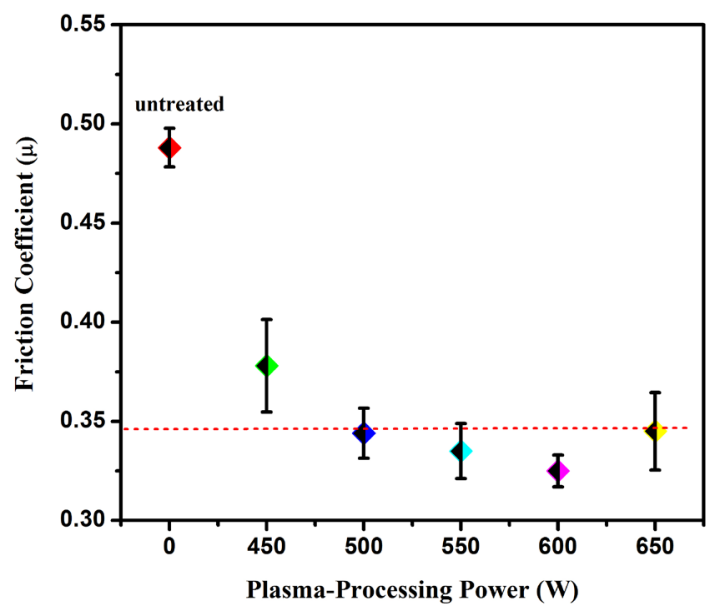

Figure 7. Friction coefficient for the untreated and carbonitrided AISI 316 at different plasma-processing powers. 


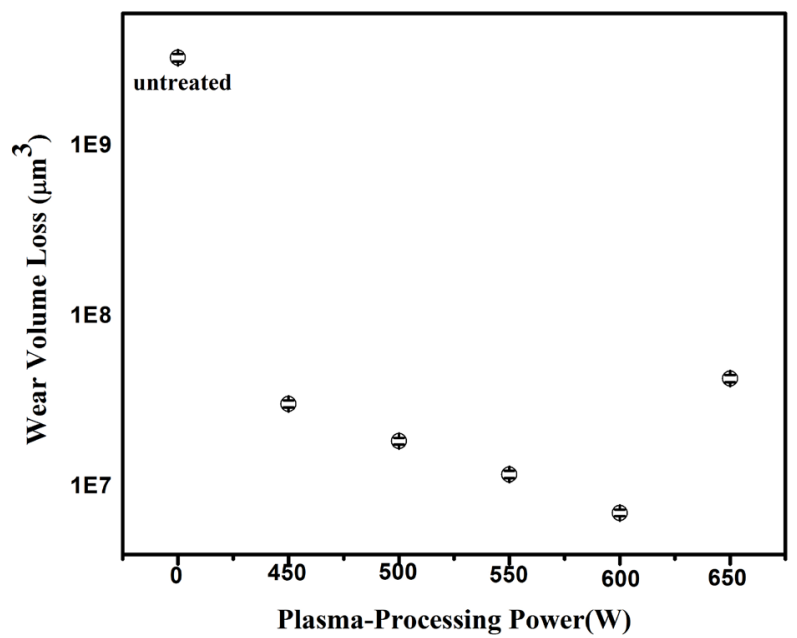

Figure 8. Wear volume loss for the untreated and carbonitrided AISI 316 at different plasma-processing powers.

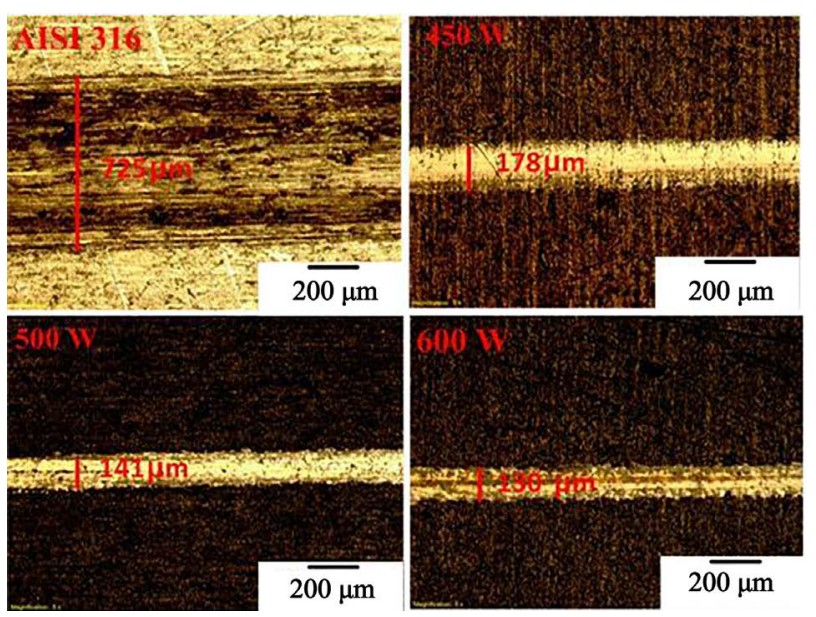

Figure 9. Optical micrographs of wear track of the untreated and carbonitrided AISI 316 at different plasma-processing powers.

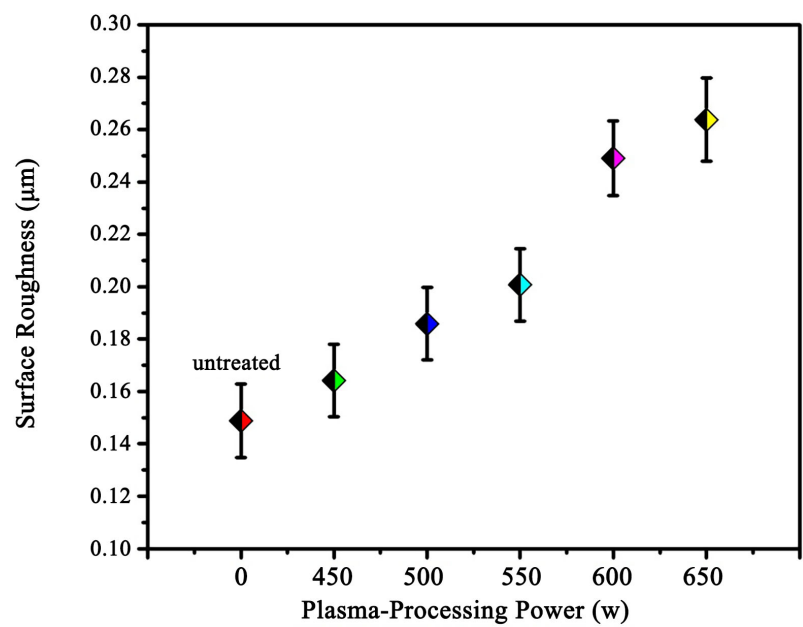

Figure 10. Average roughness $(\mathrm{Ra})$ for the untreated and treated AISI 316 samples at different plasma-processing powers. 
power input. The Ra is observed to be gradually increased from a value of 0.15 $\mu \mathrm{m}$ for the untreated substrate to a value of $0.26 \mu \mathrm{m}$ for the carbonitrided samples at $650 \mathrm{~W}$. The change in surface topography for the carbonitrided substrate in comparison with the untreated AISI 316 could be attributed to the change in surface chemical composition by forming nitrided, carbonitrided and solid solution phases in the surface. Moreover, the increase in the treatment temperature with increasing processing power will result in increasing the trembling motion of atoms in the AISI 316 matrix; making them more defenseless for spitting by the ions in the presence of self-bias potential. Further, the increase in plasma-processing power leads to increase the plasma species energy and plasma ion density which in turn increases the surface irregularities and topography during plasma surface interactions [34].

The wettability and surface energy plays significant roles in affecting the surface properties and biocompatibility features of different materials for various industrial and biomedical applications [35] [36]. They have found to be important for the investigation of protein adsorption and cellular adhesion on biomaterial surfaces [37]. The wettability can be evaluated using contact angle technique, which is based on Sessile Drop Method. Low contact angle means high wettability and high surface energy and vice versa [38]. Figure 11 shows the surface energy and contact angle for the untreated and carbonitrided AISI 316 samples at different plasma-processing powers. One can observe from the figure that the surface energy increases as the plasma-processing power increases up to $600 \mathrm{~W}$ to reach a value of $70 \mathrm{mN} / \mathrm{m}$; indicating a hydrophilicity increment. After that it decreases to reach a value of $60 \mathrm{mN} / \mathrm{m}$ for power of $650 \mathrm{~W}$; indicating a hydrophilicity reduction. The current behavior of surface energy is in a good correlation with the surface microhardness trend. There are numerous reports demonstrated that the surface energy increases with increasing the surface microhardness [9] [39]. The formation of $\mathrm{Fe}_{4} \mathrm{~N}, \gamma_{\mathrm{N}}, \gamma_{\mathrm{C}}$ and $\mathrm{CrN}$ hard phases increases the surface strengthening and consequently increases the surface energy.

It can be witnessed from the figure that the water contact angle of all untreated and treated surfaces is less than $90^{\circ}$, indicating a hydrophilicity feature. However, the lower values of water contact angle for all carbonitrided samples compared to that of the untreated one leads to high wettability and more hydrophilicity performance. These kinds of surfaces are favorable for good cells adhesion and proliferation rate.

The surface wettability can be correlated with the surface topography and surface roughness besides to the surface chemical composition. The increase in Ra value with increasing plasma power will result in increasing the surface wettability. Moreover, The $\mathrm{Rp} / \mathrm{Rz}$ (surface roughness parameters) is important ratio in describing the existence of sharp irregularities on the top surface. Rp parameter is obtained from mean peak height in relation to the central line in five consecutive readings. $\mathrm{Rz}$ is calculated by the sum of maximum peak heights $(\mathrm{Rp})$ and maximum valley depths $(\mathrm{Rv})$ in sampling length. For $\mathrm{Rp} / \mathrm{Rz}$ ratio greater than 0.5 , the surface shape shows sharp peaks whereas value lower than 0.5 in- 
dicates a surface with rounded peaks. Rounded peaks are favor to spread out the liquid over the surface. Table 1 illustrates the $\mathrm{Rp} / \mathrm{Rz}$ ratio for all carbonitrided samples which exhibited rounded peaks. Accordingly, plasma carbonitriding can be considered as an effective surface treatment technique used for changing surface chemistry, topography and in turn varying the surface wettability.

\subsection{Corrosion Performance}

Figure 12 displays the open circuit potential (OCP) versus immersion time for the untreated and carbonitrided samples in a corrosive medium of ringer's solution at room temperature. The typical value of the corrosion potential can be determined from potentiodynamic polarization tests. As shown in the figure, the open circuit potential for the untreated sample reaches a steady potential around $-125 \pm-5 \mathrm{mV}$ after few tens of seconds immersed in ranger's solution. This indicates a fast disintegration of a thin passive film (oxide layers) which forms naturally on the austenitic surface [40]. After plasma carbonitriding, this thin oxide layer is partly removed in which $\mathrm{C}$ and $\mathrm{N}$ atoms diffuses in the surface of the substrate. At the end of the diffusion process, the cortical zone of the metal is sufficiently rich in $\mathrm{C}$ and $\mathrm{N}$ to form with the base material a thin layer of amorphous carbides. This layer makes the steel less oxide-sable, leading to a nobilitation of the potential and a lower tendency to passivation in air [41]. Therefore, the treated samples can be corroded at higher potential and exhibit lower corrosion rate. The higher positive values of corrosion potential are due to the formation of a strong dense carbonitriding passive layer consists of nitrogen and carbon solid solutions [26].

Potentiodynamic polarization curve expresses anodic and cathodic polarization reactions that can take place on the immersed surface. Figure 13 shows the potentiodynamic polarization curves of the untreated and carbonitrided AISI 316 in ranger's solution. Moreover, the corrosion potential and current for all examined samples are shown in Table 2. The measured corrosion potentials for all carbonitrided AISI 316 are observed to be shifted to more positive values than the untreated. This behavior demonstrated that, the carbonitrided layer needs more energy to start the corrosion reaction [27]. The sample treated at processing power of $450 \mathrm{~W}$ shows a lower corrosion current compared to that of all other carbonitrided samples due to absence of $\mathrm{CrN}$ precipitation. The relatively higher corrosion current and low corrosion resistance that observed for the sample treated at $650 \mathrm{~W}$ is ascribed to the randomly precipitating of $\mathrm{CrN}$ on the grain boundaries [42] [43]. On the other side, the increase of the current density in the anodic part is observed for most treated samples. This is might be due to the increase in surface roughness of the treated samples as a function of processing temperature [44]. It has been previously reported that the nitrogen and carbon has a beneficial effecting in improving the corrosion potential [45] [46]. Further, the solid solution $\gamma_{\mathrm{C}}$ and $\gamma_{\mathrm{N}}$ phases have more passivity than the austenite phase [26] [47]. The variation in the corrosion behavior can be ascribed to the difference in the microstructure of the carbonitrided layer formed at different treat- 
ment temperatures. Furthermore, there is no pitting corrosion observed for all investigated samples which indicate good surface ability to form strong passive layer.

\subsection{Biocompatibility}

The purpose of growing the mesenchymal stem cells on untreated and carbonitrided 316 AISI substrates is considered for preliminary evaluating the biocompatibility performance. Figure 14 shows the growing of mesenchymal stem cells on the untreated and carbonitrided 316 AISI samples at different plasma-processing powers. It is generally accepted that, cells adhere on surface mainly via adsorbed proteins, e.g. fibronectin and vitronectin [48]. These proteins are formed by the cells as part of their own extra cellular matrix [49]. It is worth mentioning to observe that, the number of grown cells is higher on the carbonitrided substrates compared to that of the untreated one. Further, the number of grown cells increases with increasing the rf plasma-processing power. This is attributed to the increase in surface wettability, surface roughness and to the change in the structural behavior of the carbonitrided layer as a function of processing power which in turn affects the cell adhesion and cell spreading [50] [51]. The rougher surface exhibits higher number of cell adhesion which is correlated well with other previous work [52].

Table 1. Rp/Rz ratio for the untreated and carbonitrided AISI 316 treated at different plasma-processing powers.

\begin{tabular}{cccc}
\hline Samples & $\mathrm{Rz}(\mu \mathrm{m})$ & $\mathrm{Rp}(\mu \mathrm{m})$ & $\mathrm{Rp} / \mathrm{Rz}$ \\
\hline As-received AISI 316 & 2.076 & 0.893 & 0.430 \\
$450 \mathrm{~W}$ & 1.693 & 0.583 & 0.344 \\
$500 \mathrm{~W}$ & 1.702 & 0.512 & 0.301 \\
$550 \mathrm{~W}$ & 1.833 & 0.692 & 0.378 \\
$600 \mathrm{~W}$ & 2.682 & 0.987 & 0.368 \\
$650 \mathrm{~W}$ & 2.665 & 1.034 & 0.388 \\
\hline
\end{tabular}

Table 2. Corrosion data for the untreated and treated samples investigated in Ringer's solution.

\begin{tabular}{cccc}
\hline $\begin{array}{c}\text { Plasma Processing } \\
\text { Power (watt) }\end{array}$ & $\begin{array}{c}\text { Icorr } \\
\left(\mathrm{mA} / \mathrm{cm}^{2}\right)\end{array}$ & $\begin{array}{c}\text { Ecorr } \\
(\mathrm{mV})\end{array}$ & $\begin{array}{c}\text { Corrosion Rate } \\
(\mathrm{mm} / \text { Year })\end{array}$ \\
\hline As-received AISI 316 & $2.33 \mathrm{E}-03$ & 59.64 & $3.04 \mathrm{E}-02$ \\
$450 \mathrm{~W}$ & $1.98 \mathrm{E}-03$ & 236.24 & $2.59 \mathrm{E}-02$ \\
$500 \mathrm{~W}$ & $7.80 \mathrm{E}-03$ & 307.48 & $1.02 \mathrm{E}-01$ \\
$550 \mathrm{~W}$ & $2.57 \mathrm{E}-02$ & 427.58 & $3.36 \mathrm{E}-01$ \\
$600 \mathrm{~W}$ & $1.52 \mathrm{E}-02$ & 311.58 & $1.99 \mathrm{E}-01$ \\
$650 \mathrm{~W}$ & $4.26 \mathrm{E}-02$ & 360.37 & $5.57 \mathrm{E}-01$ \\
\hline
\end{tabular}




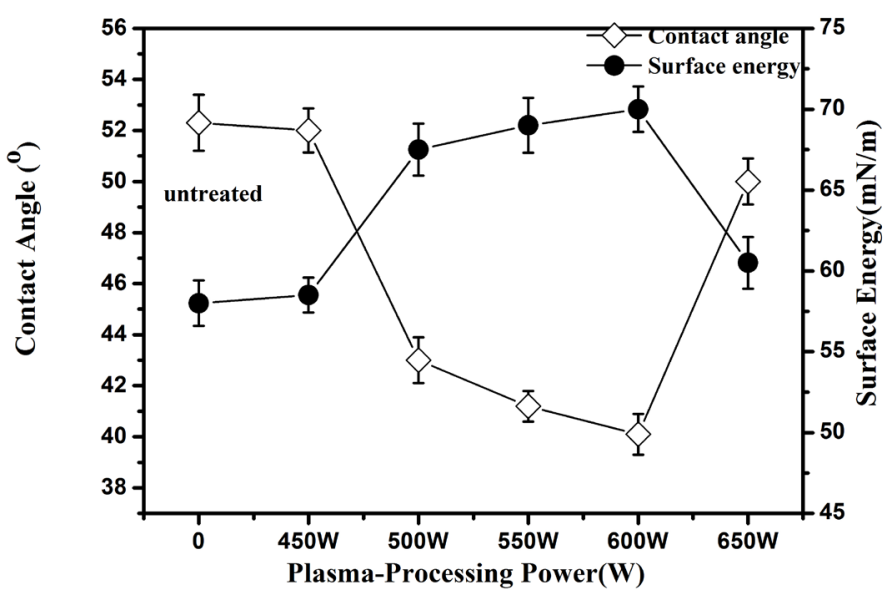

Figure 11. Surface energy and contact angle variations for the untreated and carbonitrided AISI 316 as a function of plasma-processing power.

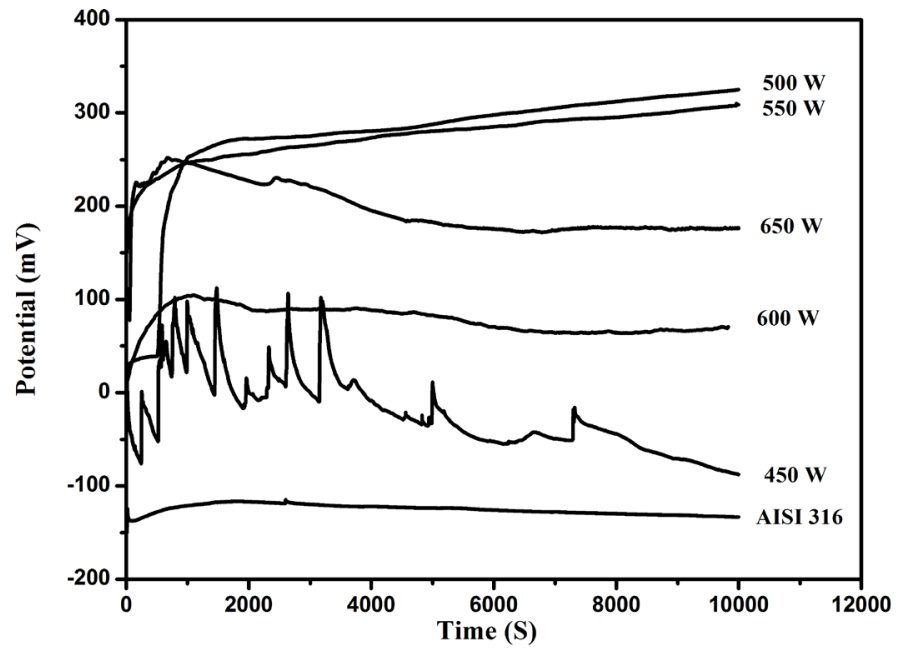

Figure 12. Open circuit potential of the untreated and carbonitrided samples; were immersed in Ringer's solution for $10000 \mathrm{~s}$.

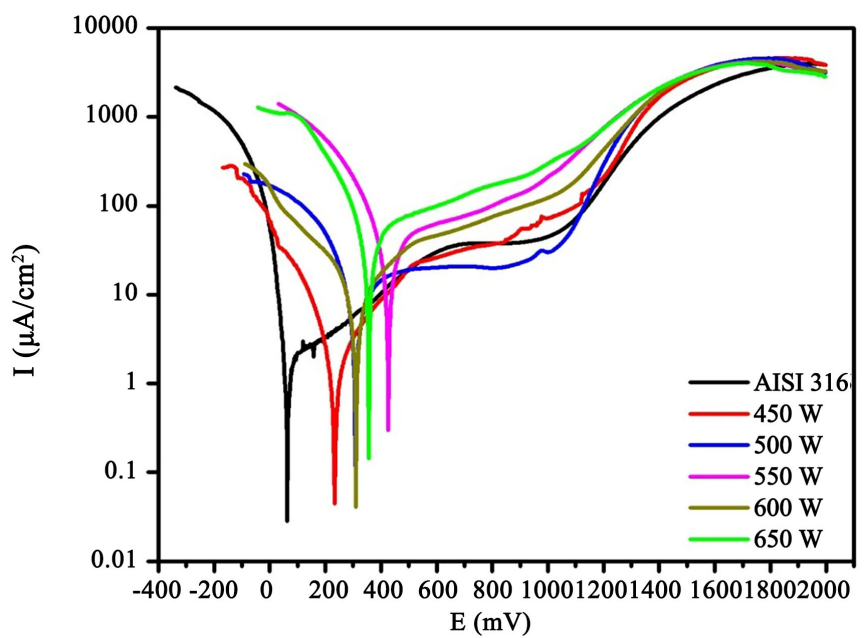

Figure 13. Tafel curves of the untreated and carbonitrided samples for different plasma-processing powers measured in Ringer's solution. 

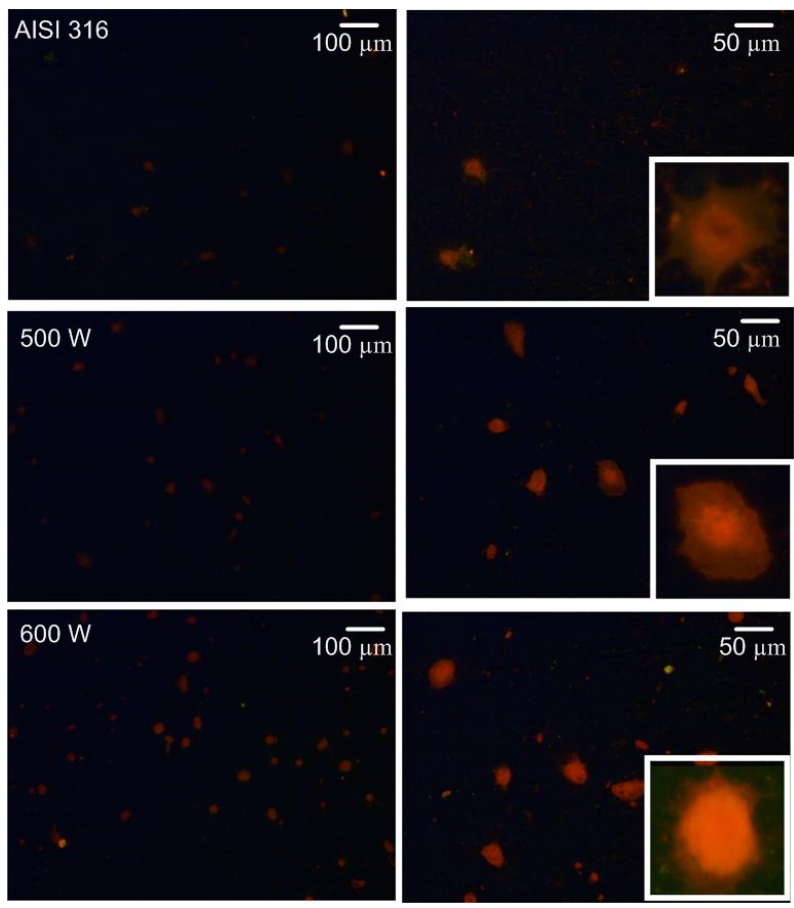

Figure 14. Mesenchymal stem cells growing on the untreated and carbonitrided AISI 316 samples at different plasma-processing powers.

\section{Conclusions}

1) A superficial modified layer has been formed with relatively high carbonitriding rate and surface hardness. Solid solution phases of $\gamma_{\mathrm{N}}$ and $\gamma_{\mathrm{C}}$ have been detected with intense peaks of $\mathrm{Fe}_{3} \mathrm{C}$ and $\mathrm{FeC}$ for AISI 316 treated at lower plasma processing power. Moreover, $\mathrm{CrN}$ is detected in all samples treated at high processing powers.

2) The tribological performance of the carbonitrided layer has been improved with a significant decrease in the friction coefficient and increase in the wear resistance. The contact angle of the modified surface, and thus the wettability can be controlled through controlling the plasma-processing power. The corrosion resistance is improved after carbonitrding of AISI 316 sample at lowest power of $450 \mathrm{~W}$.

3) The biocompatibility performance is improved after plasma carbonitriding process and is demonstrated by increasing the number of grown mesenchymal stem cells for carbonitrided substrates compared to that of the untreated AISI 316

4) From the present study, it has been concluded that the rf plasma carbonitriding is effectively improving the physical and chemical properties and enhancing the biocompatibility performance of AISI 316 austenitic stainless steel.

\section{Conflicts of Interest}

The authors declare no conflicts of interest regarding the publication of this paper. 


\section{References}

[1] Johansson, B., Vitos, L. and Korzhavyi, P.A. (2003) Chemical Composition-Elastic Property Maps of Austenitic Stainless Steels. Solid State Sciences, 5, 931-936. https://doi.org/10.1016/S1293-2558(03)00118-3

[2] Hoshiyama, Y., Mizobata, R. and Miyake, H. (2016) Mechanical Properties of Austenitic Stainless Steel Treated by Active Screen Plasma Nitriding. Surface and Coatings Technology, 307, 1041.

[3] Kusmano, S.A., Dyakov, I.G., Kusmanova, Y.V. and Belkin, P.N. (2016) Surface Modification of Low-Carbon Steels by Plasma Electrolytic Nitrocarburising. Plasma Chemistry and Plasma Processing, 36, 1271.

[4] Lee, I. and Barua, A. (2016) Behavior of the S-Phase of Plasma Nitrocarburized 316L Austenitic Stainless Steel on Changing Pulse Frequency and Discharge Voltage at Fixed Pulse-Off Time. Surface and Coatings Technology, 307, 1045.

[5] Sonmez, T., Jadidi, M.F., Kazmanli, K., Birer, Ö. and Ürgen, M. (2016) Role of Different Plasma Gases on the Surface Chemistry and Wettability of RF Plasma Treated Stainless Steel. Vacuum, 129, 63-73.

https://doi.org/10.1016/j.vacuum.2016.04.014

[6] Abd El-Rahman, A.M., El-Hossary, F.M., Fitz, T., Negm, N.Z., Prokert, F., Pham, M.T., et al. (2004) Effect of $\mathrm{N}_{2}$ to $\mathrm{C}_{2} \mathrm{H}_{2}$ Ratio on r.f. Plasma Surface Treatment of Austenitic Stainless Steel. Surface and Coatings Technology, 183, 268-274. https://doi.org/10.1016/j.surfcoat.2003.09.057

[7] Kan, I.J., Ko, M.G., Yang, J.K. and Lee, H.J. (2013) Plasma Surface Treatments by Using a Dielectric Barrier Discharge for the Deposition of Diamond Films. Journal of the Korean Physical Society, 63, 199-205. https://doi.org/10.3938/jkps.63.199

[8] El-Hossary, F.M., Negm, N.Z., Khalil, S.M., Abed El-Rahman, A.M., Raaif, M. and Mändl, S. (2010) Effect of Annealing Temperature on Hardness, Thickness and Phase Structure of Carbonitrided 304 Stainless Steel. Applied Physics A, 99, 489-495. https://doi.org/10.1007/s00339-010-5564-9

[9] EL-Hossary, F.M., Abd EL-Rahman, A.M., Raaif, M., Seleem, A.A. and Abo El-Kassem, M. (2014) Effect of rf Plasma Carbonitriding on the Biocompatibility and Mechanical Properties of AISI 321 Austenitic Stainless Steel. Advanced in Materials Physics and Chemistry, 4, 33-42.

[10] Buhagiar, J., Jung, A., Gouriou, D., Mallia, B. and Dong, H. (2013) S-Phase against S-Phase Tribopairs for Biomedical Applications. Wear, 301, 280-289. https://doi.org/10.1016/j.wear.2012.12.012

[11] Nosei L., Farina, S., Ávalos, M., Náchez, L., Gómez, B.J. and Feugeas, J. (2008) Corrosion Behavior of Ion Nitrided AISI 316L Stainless Steel. Thin Solid Films, 516, 1044-1050. https://doi.org/10.1016/j.tsf.2007.08.072

[12] Borgioli, F., Galvanetto, E. and Bacci, T. (2016) Low Temperature Nitriding of AISI 300 and 200 Series Austenitic Stainless Steels. Vacuum, 127, 51-60. https://doi.org/10.1016/j.vacuum.2016.02.009

[13] Sun, Y. and Haruman, E. (2011) Effect of Electrochemical Potential on Tribocorrosion Behavior of Low Temperature Plasma Carburized 316L Stainless Steel in $1 \mathrm{M}$ $\mathrm{H}_{2} \mathrm{SO}_{4}$ Solution. Surface and Coatings Technology, 205, 4280-4290. https://doi.org/10.1016/j.surfcoat.2011.03.048

[14] El-Hossary, F.M., Negm, N.Z., Khalil, S.M. and Abd El-Rahman, A.M. (2002) Formation and Properties of a Carbonitrided Layer in 304 Stainless Steel Using Different Radio Frequency Plasma Powers. Thin Solid Films, 405, 179-185. 
https://doi.org/10.1016/S0040-6090(01)01729-1

[15] ASTM International (2011) Standard Test Method for Knoop and Vickers Hardness of Materials. West Conshohocken, PA. https://doi.org/10.1520/E0384-11

[16] Perl, D.P. and Little, B.N. (1980) Acridine Orange-Nucleic Acid Fluorescence Its Use in Routine Diagnostic Muscle Biopsies. Archives of Neurology, 37, 641-644. https://doi.org/10.1001/archneur.1980.00500590065011

[17] Ribble, D., Goldstein, N.B., Norris, D.A. and Shellman, Y.G. (2005) A Simple Technique for Quantifying Apoptosis in 96-Well Plates. BMC Biotechnology, 12, 1186.

[18] El-Hossary, F.M., Negm, N.Z., Khalil, S.M. and Raaif, M. (2006) Surface Modification of Titanium by Radio Frequency Plasma Nitriding. Thin Solid Films, 497, 196-202. https://doi.org/10.1016/j.tsf.2005.09.193

[19] Abd El-Rahman, A.M. (2010) An Investigation on the Microstructure, Tribological and Corrosion Performance of AISI 321 Stainless Steel Carbonitrided by RF Plasma Process. Surface and Coatings Technology, 205, 674-681. https://doi.org/10.1016/j.surfcoat.2010.08.036

[20] Baranowska, J. and Franklin, S.E. (2008) Characterization of Gas-Nitrided Austenitic Steel with an Amorphous/Nanocrystalline Top Layer. Wear, 264, 899-903. https://doi.org/10.1016/j.wear.2006.12.074

[21] Figueroa, C.A. and Alvarez, F. (2005) Structural Modifications and Corrosion Behavior of Martensitic Stainless Steel Nitrided by Plasma Immersion Ion Implantation. Journal of Vacuum Science \& Technology A, 23, 693.

[22] El-Hossary, F.M. (2002) The Influence of Surface Microcracks and Temperature Gradients on the rf Plasma Nitriding Rate. Surface and Coatings Technology, 150, 277-281. https://doi.org/10.1016/S0257-8972(01)01524-9

[23] Tibbetts, G.G. (1974) Role of Nitrogen Atoms in "Ion-Nitriding". Journal of Applied Physics, 45, 5072. https://doi.org/10.1063/1.1663186

[24] Li, Y., Zhang, S.Z., He, Y.Y., Zhang, L. and Wang, L. (2014) Characteristics of the Nitrided Layer Formed on AISI 304 Austenitic Stainless Steel by High Temperature Nitriding Assisted Hollow Cathode Discharge. Materials and Design, 64, 527-534. https://doi.org/10.1016/j.matdes.2014.08.023

[25] Xu, X.L., Wang, U.L., Yu, Z.W. and Hei, Z.K. (2000) Microstructural Characterization of Plasma Nitrided Austenitic Stainless Steel. Surface and Coatings Technology, 132, 270-274. https://doi.org/10.1016/S0257-8972(00)00905-1

[26] Dong, H., Q, P.Y., Li, X.Y. and Llewellyn, R.J. (2006) Improving the Erosion-Corrosion Resistance of AISI 316 Austenitic Stainless Steel by Low-Temperature Plasma Surface Alloying with $\mathrm{N}$ and C. Materials Science and Engineering: A, 431, 137-145. https://doi.org/10.1016/j.msea.2006.05.122

[27] Huang, C.H., Huang, J.C., Li, J.B. and Jang, J.S.C. (2013) Simulated Body Fluid Electrochemical Response of Zr-Based Metallic Glasses with Different Degrees of Crystallization. Materials Science and Engineering: C, 33, 4183-4187. https://doi.org/10.1016/j.msec.2013.06.007

[28] Abedi, H.R., Salehi, M. and Yazdkhasti, M. (2010) Novel Plasma Nitriding-Oxidizing Duplex Treatment of AISI 316 Austenitic Stainless Steel. Materials Letters, 64, 698-701. https://doi.org/10.1016/j.matlet.2009.12.042

[29] Terent'ev, V.F., Michugina, M.S., Kolmakov, A.G., Kvedaras, V., Ciuplys, V., Ciuplys, A. and Vilys, J. (2007) The Effect of Nitriding on Fatigue Strength of Structural Alloys. Mechanika, 64, 12. 
[30] Lee, C.X. and Bell, T. (2004) Sliding Wear Properties of Active Screen Plasma Nitrided 316 Austenitic Stainless Steel. Wear, 256, 1144-1152. https://doi.org/10.1016/S0043-1648(03)00512-X

[31] Alam, A.U., Howlader, M.M.R. and Deen, M.J. (2014) The Effects of Oxygen Plasma and Humidity on Surface Roughness, Water Contact Angle and Hardness of Silicon, Silicon Dioxide and Glass. Journal of Micromechanics and Microengineering, 24, Article ID: 035010. https://doi.org/10.1088/0960-1317/24/3/035010

[32] Yerokhin, A.L., Leyland, A., Tsotsos, C., Wilson, A.D., Nie, X. and Matthews, A. (2001) Duplex Surface Treatments Combining Plasma Electrolytic Nitrocarburising and Plasma-Immersion Ion-Assisted Deposition. Surface and Coatings Technology, 142-144, 1129-1136. https://doi.org/10.1016/S0257-8972(01)01097-0

[33] Bizi-Bandoki, P., Benayoun, S., Valette, S., Beaugiraud, B. and Audouard, E. (2011) Modifications of Roughness and Wettability Properties of Metals Induced by Femtosecond Laser Treatment. Applied Surface Science, 257, 5213-5218. https://doi.org/10.1016/j.apsusc.2010.12.089

[34] Bong-Yong, J. and Myung-Ho, K. (2001) Effects of Pulse Frequency and Temperature on the Nitride Layer and Surface Characteristics of Plasma Nitrided Stainless Steel. Surface and Coatings Technology, 137, 249-254. https://doi.org/10.1016/S0257-8972(00)01095-1

[35] Liu, Y.F., Mu, J.S., Xu, X.Y. and Yang, S.Z. (2007) Microstructure and Dry-Sliding Wear Properties of TiC-Reinforced Composite Coating Prepared by Plasma-Transferred arc Weld-Surfacing Process. Materials Science and Engineering, 458, 366-370. https://doi.org/10.1016/j.msea.2006.12.086

[36] Xiaomei, L., Lim Jung, Y., Donahue Henry, J., Dhurjati, R., Mastro Andrea, M. and Vogler Erwin, A. (2007) Influence of Substratum Surface Chemistry/Energy and Topography on the Human Fetal Osteoblastic Cell Line hFOB 1.19: Phenotypic and Genotypic Responses Observed in Vitro. Biomaterials, 28, 4535-4550. https://doi.org/10.1016/j.biomaterials.2007.06.016

[37] Chu, P.K., Chen, J.Y., Wang, L.P. and Huang, N. (2002) Plasma-Surface Modification of Biomaterials. Materials Science and Engineering: R: Reports, 36, 143-206. https://doi.org/10.1016/S0927-796X(02)00004-9

[38] Kasemo, B. (2002) Biological Surface Science. Surface Science, 500, 656-677. https://doi.org/10.1016/S0039-6028(01)01809-X

[39] Raaif, M., El-Hossary, F.M., Negm, N.Z., Khalil, S.M. and Schaaf, P. (2007) Surface Treatment of Ti-6Al-4V Alloy by rf Plasma Nitriding. Journal of Physics. Condensed Matter, 19, Article ID: 396003. https://doi.org/10.1088/0953-8984/19/39/396003

[40] Gurappa, I. (2002) Characterization of Different Materials for Corrosion Resistance under Simulated Body Fluid Conditions. Materials Characterization, 49, 73-79. https://doi.org/10.1016/S1044-5803(02)00320-0

[41] Ceschini, L., Chiavari, C., Lanzoni, E. and Martini, C. (2012) Low-Temperature Carburised AISI 316L Austenitic Stainless Steel: Wear and Corrosion Behavior. Materials and Design, 38, 154-160. https://doi.org/10.1016/j.matdes.2012.02.019

[42] Fossati, A., Borgioli, F., Galvanetto, E. and Bacci, T. (2006) Corrosion Resistance Properties of Glow-Discharge Nitrided AISI 316L Austenitic Stainless Steel in $\mathrm{NaCl}$ Solutions. Corrosion Science, 48, 1513-1527. https://doi.org/10.1016/j.corsci.2005.06.006

[43] Fossati, A., Borgioli, F., Galvanetto, E. and Bacci, T. (2006) Glow-Discharge Nitriding of AISI 316L Austenitic Stainless Steel: Influence of Treatment Time. Surface 
and Coatings Technology, 200, 3511-3517.

https://doi.org/10.1016/j.surfcoat.2004.10.122

[44] Pohrelyuk, I.M., Fedirko, V.M., Tkachuk, O.V. and Proskurnyak, R.V. (2013) Corrosion Resistance of Ti-6Al-4V Alloy with Nitride Coatings in Ringer's Solution. Corrosion Resistance, 66, 392.

[45] Tsai, W.T. and Chou, S.L. (2000) Environmentally Assisted Cracking Behavior of Duplex Stainless Steel in Concentrated Sodium Chloride Solution. Corrosion Science, 42, 1741-1762. https://doi.org/10.1016/S0010-938X(00)00029-9

[46] Chiba, A., Koyama, M., Akiyama, E. and Nishimura, T. (2018) Interstitial Carbon Enhanced Corrosion Resistance of Fe-33Mn-xC Austenitic Steels: Inhibition of Anodic Dissolution. Journal of the Electrochemical Society, 165, C19-C26. https://doi.org/10.1149/2.0661802jes

[47] Esfandiari, M. and Dong, H. (2007) The Corrosion and Corrosion-Wear Behaviour of Plasma Nitrided 17-4PH Precipitation Hardening Stainless Steel. Surface and Coatings Technology, 202, 466-478. https://doi.org/10.1016/j.surfcoat.2007.06.069

[48] Siebers, M.C., Bruggeter, P.J., Walboomers, X.F. and Jansen, J.A. (2005) Integrins as Linker Proteins between Osteoblasts and Bone Replacing Materials. A Critical Review. Biomaterials, 26, 137-146. https://doi.org/10.1016/j.biomaterials.2004.02.021

[49] Koenig, A.L., Gambillara, V., Grainger, D.W. and Rosa, A.L. (2013) Correlating Fibronectin Adsorption with Endothelial Cell Adhesion and Signaling on Polymer Substrates. Journal of Biomedical Materials Research Part A, 64, 20.

[50] Ferraz, E.P., Sa, J.C., de Oliveira, P.T., Alves, C., Beloti, M.M. and Rosa, A.L. (2013) The Effect of Plasma-Nitrided Titanium Surfaces on Osteoblastic Cell Adhesion, Proliferation, and Differentiation. Journal of Biomedical Materials Research Part A, 102, 991-998. https://doi.org/10.1002/jbm.a.34761

[51] Anselme, K., Linez, P., Bigerelle, M., Le Manger, D., Le Manger, A., Hardouin, P., et al. (2000) The Relative Influence of the Topography and Chemistry of TiAl6V4 Surfaces on Osteoblastic Cell Behavior. Biomaterials, 21, 1567-1577. https://doi.org/10.1016/S0142-9612(00)00042-9

[52] Kubies, D., Himmlová, L., Riedel, T., Chánová, E., BalÎ́k, K., Douděrová, M., et al. (2011) The Interaction of Osteoblasts with Bone-Implant Materials: 1. The Effect of Physicochemical Surface Properties of Implant Materials. Physiological Research, 60,95 . 